

\section{PROBABILITAS DEFAULT PADA PERUSAHAAN MANUFAKTUR DI INDONESIA}

Dr. Ani Nuraini, MM

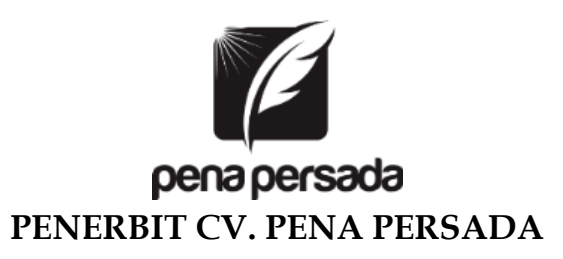




\title{
PROBABILITAS DEFAULT PADA PERUSAHAAN MANUFAKTUR DI INDONESIA
}

\author{
Penulis: \\ Dr. Ani Nuraini, MM \\ ISBN : 978-623-315-297-6
}

\author{
Editor: \\ Wiwit Kurniawan \\ Design Cover : \\ Retnani Nur Briliant \\ Layout : \\ Eka Safitry
}

\section{Penerbit CV. Pena Persada \\ Redaksi :}

Jl. Gerilya No. 292 Purwokerto Selatan, Kab. Banyumas

Jawa Tengah

Email : penerbit.penapersada@gmail.com

Website : penapersada.com Phone : (0281) 7771388

Anggota IKAPI

All right reserved

Cetakan pertama : 02 Mei 2021

Hak Cipta dilindungi oleh undang-undang. Dilarang memperbanyak karya tulis ini dalam bentuk apapun tanpa izin penerbit 


\section{KATA PENGANTAR}

Segala puji senantiasa kita panjatkan kehadirat Allah SWT, atas segala rahmat dan karunianya, akhirnya penulis dapat menyelesaikan penyusunan buku yang berjudul PROBABILITAS DEFAULT PADA PERUSAHAAN MANUFAKTUR DI INDONESIA". Saya menyadari bahwa tanpa bantuan dan bimbingan dari berbagai pihak sangatlah sulit bagi saya untuk menyelesaikan karya ini. Oleh karena itu, saya mengucapkan banyak terima kasih pada semua pihak yang telah membantu penyusunan buku ini. Sehingga buku ini bisa hadir di hadapan pembaca.

Dalam buku ini membahas tentang pengaruh informasi non finansial yang terdiri dari variabel Corporate Governance, $R \& D$, Informasi Pasar dan Faktor Makro yang di mediasi oleh Informasi Finansial berupa Financial Performance yang terdiri dari $C R$, TATO, DAR dan ROE, dengan menggunakan pengaruh tidak langsung dan pengaruh langsung terhadap Probabilitas Default. Dalam hasil kajian menemukan bahwa Financial Performance yang berpengaruh signifikan Corporate Governance, R\&D, Informasi Pasar, sedangkan Faktor Makro yang signifikan adalah interest, akan tetapi R\&D memberikan pengaruh menurunkan Financial Performance. Tahap kedua regresi logistik dengan variabel dependen Probabilitas Default yang signifikan Financial Performance, Corporate Governance dan Informasi Pasar, sedangkan R\&D, faktor makro dan variabel kontrol tidak signifikan secara langsung, akan tetapi dengan mediasi Financial Performance variabel R\&D dan variabel makro interest signifikan dalam mempengaruhi Probabilitas Default.

Penulis menyadari bahwa buku ini masih jauh dari kesempurnaan. Oleh karena itu kritik dan saran yang membangun sangat dibutuhkan guna penyempurnaan buku ini. Akhir kata saya berharap Allah SWT berkenan membalas segala kebaikan semua pihak yang telah membantu

Penulis 


\section{DAFTAR ISI}

KATA PENGANTAR ................................................................... iii

DAFTAR ISI ................................................................................

BAB I PENDAHULUAN ................................................................ 1

A. Masalah Keuangan Perusahaan......................................... 1

B. Industri Sektor Manufaktur.............................................4

BAB II KINERJA PERUSAHAAN .................................................. 7

A. Kesulitan Keuangan (Financial Distress) ........................... 7

B. Tata Kelola .................................................................. 16

C. Kinerja Keuangan ........................................................... 20

1. Rasio Likuiditas .......................................................... 22

2. Rasio Aktivitas .......................................................... 23

3. Rasio Solvabilitas..................................................... 23

4. Rasio Profitabilitas .................................................. 24

BAB III PENGARUH MAKRO DAN SISI INTERNAL PERUSAHAAN........................................................................... 25

A. Faktor Makro ................................................................ 25

B. Informasi Pasar ............................................................... 28

C. Firm Size …........................................................... 32

D. Firm Age ….............................................................33

E. Penelitian dan Pengembangan (R\&D) .............................34

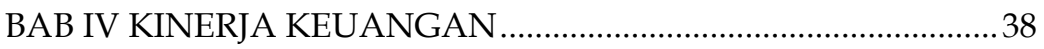

A. Pengertian Kinerjaa Keuangan ........................................38

B. Tahapan-tahapan Dalam Menganalisis Kinerja Keuangan ......................................................... 38

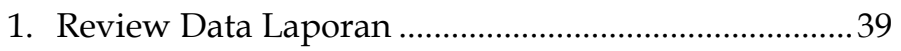

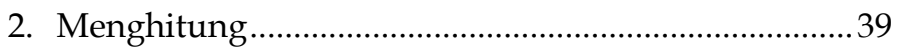

3. Membandingkan atau Mengukur ..............................3 39 
4. Menginterpretasi..............................................................40

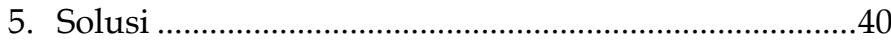

BAB V PROFITABLITAS DEFAULT ...............................................41

A. Financial Performance dan Probabilitas

Default.

B. Firm size dan Probabilitas Default ....................................42

C. Firm age dan Probabilitas Default ..........................................43

D. Corporate Governance dan Probabilitas Default

E. R\&D dan Probabilitas Default .............................................45

F. Informasi Pasar (MB) dan Probabilitas

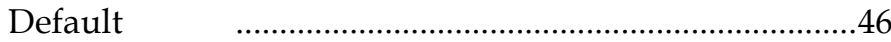

G. Makro Ekonomi dan probabilitas default............................48

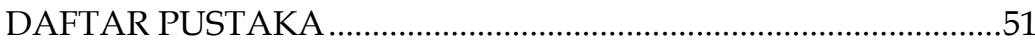

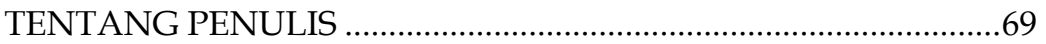




\section{PROBABILITAS DEFAULT PADA PERUSAHAAN MANUFAKTUR DI INDONESIA}




\section{BAB I \\ PENDAHULUAN}

\section{A. Masalah Keuangan Perusahaan}

Ancaman kebangkrutan selalu membayangi semua perusahaan, dan tidak hanya pada perusahaan yang berskala kecil dan baru, bahkan perusahaan yang besar akan mengalami ancaman tersebut. Beberapa perusahaan besar di dunia bahkan sudah mapan dan yang sudah berusia ratusan tahun dapat mengalami kebangkrutan. Kebangkrutan pada umumnya bermula pada perusahaan yang mempunyai hutang yang besar dan terjadi kesalahan dalam manajemen, kecurangan dalam laporan keuangan, kurangnya inovasi dalam mengantisipasi perkembangan teknologi yang cepat dan dinamis (Dmd, 2016).

Perusahaan besar dunia pernah mengalami kesulitan keuangan dan kebangkrutan. Perusahaan-perusahaan tersebut diantaranya Enron yang merupakan perusahaan bidang energi yang mengalami kebangkrutan pada tahun 2001, selanjutnya ada perusahaan WorldCom yang merupakan perusahaan telekomunikasi terbesar ke dua di Amerika menyatakan pailit pada tahun 2002, pada puncak krisis September 2008 perusahaan terbesar di bidang investasi Lehman Brothers mengalami hal yang sama ditambah dengan tidak adanya bantuan dari pemerintah yang memperparah kondisi keuangan perusahaan tersebut, MF Global tradings merupakan perusahaan pialang derivatif yang sudah berusia 200 tahun terjebak dalam spekulasi pada surat utang Eropa yang akhirnya menyatakan pailit pada September 2008, diikuti oleh Washington Mutual pada tahun yang sama yaitu 2008. 
Perusahaan Chrysler 2009 mengajukan kebangkrutannya, akan tetapi dapat diselamatkan setelah ada kerjasama dengan Fiat yang merupakan hasil mediasi yang dibantu oleh pemerintah Amerika, diikuti oleh General Motor pada Juni 2009 yang mengajukan perlindungan terhadap kebangkrutan melalui petisi, setelah empat tahun dari terjadinya krisis global 2008 perusahaan di bidang percetakan dan film yang sudah berusia 125 tahun yakni Kodak mengajukan perlindungan kebangkrutan, diikuti oleh perusahaan bidang videogame yaitu Atari Inc. dan Blockbuster pada tahun 2013. Pada tahun 2015 Radioshack adalah perusahaan yang selalu memberikan kejutan dalam inovasi produk bidang tekhnologi pada era 1950 - 1970 an, akhirnya mengalami kebangkrutan, diikuti oleh MGM perusahaan studio film terbesar yang menyatakan pailit.

Tabel 1. 1 Data Kebangkrutan Perusahaan Besar Dunia

\begin{tabular}{|c|c|c|c|c|c|}
\hline No. & Nama Perusahaan & $\begin{array}{c}\text { Tahun } \\
\text { Bangkrut }\end{array}$ & Sektor/Bidang & Asset/ Hutang & Penyebab Bangkrut \\
\hline 1 & Enron & 2001 & Energidid Houston & Hutang USD 31.2 milliar & $\begin{array}{l}\text { jumlah hutang besar dan aset minim, } \\
\text { manipulasi laporan keuangan sistematis } \\
\text { terlembaga dan direncanakan, menurunnya } \\
\text { kredit rating }\end{array}$ \\
\hline 2 & WorldCom & 2002 & Telekomunikasi Amerika Serikat & Asset USD 103.9 miliar & kecurangan dalam laporan keuangan \\
\hline 3 & Lehman Brothers & 2008 & Investment Bank Amerika Serikat & Asset USD 691 mililar & subprime mortgage \\
\hline 4 & MFGlobal Holdings & 2008 & Pialang derivatif & $\begin{array}{l}\text { Hutang obligasi Eropa USD } 6 \\
\text { millar }\end{array}$ & 6 default pada surat utang \\
\hline 5 & Washington Mutual (WaMu) & 2008 & Perbankan & Asset USD 307 miliar & kesalahan manajemen \\
\hline 6 & Chrysler & 2009 & Manufaktur mobil & Rugi USD 200 juta & kekurangan likuiditas \\
\hline 7 & General Motors & 2009 & Manufaktur automotif & USD 91 milliar & $\begin{array}{l}\text { persaingan ketat dengan mobil Jepang dan } \\
\text { besarnya biaya tenaga kerja }\end{array}$ \\
\hline 8 & Kodak & 2012 & Film, kamera dan industri percetakan & Hutang USD 3.4 mililar & manajemen buruk dan kurang inovasi \\
\hline 9 & Atarilnc & 2013 & Konsol video game & Hutang 21 juta euro & perrsahhaan induk terlibat banyak utang \\
\hline 10 & Blockbuster & 2013 & Penyewaan Video dan DVD & Hutang USD 900 juta & $\begin{array}{l}\text { menutup } 300 \text { cabang, tidak mampu } \\
\text { menyikapi internet dan inovasi }\end{array}$ \\
\hline 11 & RadioShack & 2015 & Alat elektronik dan telpon seluler & Rugi USD 98.3 juta & $\begin{array}{l}\text { tahun 1950-1970 terdepan dalam inovasi, } \\
\text { saat ini ketinggalan teknologinya }\end{array}$ \\
\hline 12 & MGM & 2010 & Studio film & Hutang USD 4 millar & jumlah hutang yang besar \\
\hline
\end{tabular}

Sumber : diolah peneliti 
Beberapa perusahaan di Indonesia juga mengalami hal yang sama yaitu adanya kebangkrutan atau pailit pada kurun waktu tahun 2016 - 2019, dan merupakan perusahaan yang besar serta sudah cukup lama beroperasi seperti Nyonya Meneer, Sariwangi, Royal Standar dan seterusnya (Sari, 2017). Tahun 2019 beberapa perusahaan besar juga mengalami default diantaranya Duniatex dan Krakatau Steel, perusahaan tersebut termasuk perusahaan bidang manufaktur yang cukup besar, sedangkan Jababeka diperkirakan akan mengalami hal yang sama yaitu default, hal ini dikarenakan adanya kewajiban hutang yang jatuh tempo akan tetapi perusahaan tersebut tidak dapat memenuhi kewajibannya.

Tabel 1. 2 Data beberapa perusahaan default tahun 2016 - 2019 di

\section{Indonesia}

\begin{tabular}{|c|c|c|c|c|c|}
\hline №. & Nama Perusahaan & $\begin{array}{c}\text { Tahun } \\
\text { Bangkrut }\end{array}$ & produsen & Asset/ Hutang & Penyebab Bangkrut \\
\hline & PT. Megalestari Unggul & 2017 & KTP elektronik & Hutang Rp. $376 . .84$ miliar & $\begin{array}{l}\text { tidak melaksanakan tata kelola yang baik, } \\
\text { melakukan korupsi }\end{array}$ \\
\hline & $\begin{array}{l}\text { PT. Citra Maharlika } \\
\text { Nusantara (Cipaganti) }\end{array}$ & 2017 & jasa transportasi & Hutang Rp. 245 miliar & $\begin{array}{l}\text { hutang yang besar terhadap pajak dan } \\
\text { kreditor }\end{array}$ \\
\hline & PT. Multicon Indraja Terminal & 2017 & petikemas & Hutang Rp. 678.03 miliar & hutang yang besar \\
\hline & PT. Kimas Internusa & 2016 & ritel telepon seluler & Hutang Rp. 758.40 miliar & hutang yang besar \\
\hline & PT. Petroselat Ltd. & 2018 & kontraktor minyak dan gas bumi & Hutang Rp. 758.40 miliar & hutang yang besar dari 47 kreditur \\
\hline & PT. Asia Paper Mills & 2017 & kertas dan plastik kemasan & Hutang Rp. 568 miliar & hutang yang besar \\
\hline & $\begin{array}{l}\text { PT. Dwi Aneka Jaya } \\
\text { Kemasindo }\end{array}$ & 2017 & kemasan kertas dan karton & $\begin{array}{l}\text { Hutang Rp. } 777.68 \text { miliar } \\
\text { Asset Rp. } 1.3 \text { triliun } \\
\text { Rugi Rp. } 59.61 \text { miliar }\end{array}$ & $\begin{array}{l}\text { hutang yang besar dari beberapa kreditur } \\
\text { bank }\end{array}$ \\
\hline & PT. Sariwangi & 2018 & Industri perkebunan & Hutang Rp. 1.05 triliun & $\begin{array}{l}\text { gagal dalam investasi bidang teknologi, tidak } \\
\text { sesuai yang diharapkan }\end{array}$ \\
\hline & Nyonya Meneer & 2017 & Industrij jamu & Hutang Rp. 7.4 miliar & $\begin{array}{l}\text { krisis operasional yang cukup lama dan } \\
\text { permasalahan sengketa keluarga }\end{array}$ \\
\hline & Seven-Eleven & 2017 & Restoran dan convenience & Hutang Rp. 238 miliar & $\begin{array}{l}\text { besarnya biaya operasional sewa dan biaya } \\
\text { infrastruktur sarana yang sumber dananya } \\
\text { dari hutang }\end{array}$ \\
\hline & Duniatex & 2019 & tekstil & Hutang Rp. 18.79 triliun & perang dagang Amerika dan China \\
\hline & Royal Standar (amplop jaya) & 2018 & Amplop dan buku & Hutang Rp. 1.28 triliun & hutang yang besar dari 23 kreditur \\
\hline
\end{tabular}

Sumber : diolah peneliti 
Berbagai permasalahan kesulitan keuangan yang dialami perusahaan tersebut di atas mengakibatkan default dan kebangkrutan, seperti yang terjadi pada Duniatex perusahaan tekstil terbesar di Indonesia mengalami gagal bayar pada anak perusahaannya, hal ini disebabkan oleh perang dagang Amerika dan China yang menyebabkan menurunnya keuntungan, dan obligasi yang jatuh tempo menjadi default.

\section{B. Industri Sektor Manufaktur}

Krakatau Steel mengalami kerugian selama tujuh tahun berturut-turut hal ini disebabkan karena kurang mengantisipasi adanya persaingan yang semakin ketat, sehingga mengalami kerugian dan tidak bisa menutupi hutangnya. Permasalahan-permasalahan pada perusahaan tersebut di atas lebih banyak dikarenakan hutang yang besar dan perusahaan tidak mengelola hutangnya dengan baik, bahkan hutang digunakan untuk membiayai biaya operasional yang akhirnya pada saat jatuh tempo perusahaan tersebut kekurangan dana untuk membayar hutangnya yang menyebabkan default.

Permasalahan lain dari perusahaan tersebut di atas adalah dengan menggunakan hutang yang besar untuk melakukan investasi pada bidang teknologi seperti yang dilakukan oleh perusahaan penghasil teh sari wangi. Hasil investasi ternyata tidak sesuai dengan yang diharapkan, hal ini bisa disebabkan perusahaan tidak atau belum melakukan research and development dengan baik sebelum melakukan investasi dengan menggunakan pendanaan yang berasal dari hutang pihak eksternal sehingga mengakibatkan terjadinya default.

Semenjak terjadinya krisis global pada tahun 2008, beberapa industri manufaktur di Indonesia terkena dampaknya, khususnya produk kebutuhan pasar global pada triwulan ke-empat terjadi pertumbuhan yang lambat diantaranya industri tekstil, barang kulit dan alas kaki, 
industri kertas dan barang cetakan, industri logam dasar, besi dan baja, mesin dan peralatan. Melemahnya permintaan akibat krisis global tidak hanya pasar global tetapi juga pasar domestik (Pemerintah, 2008). Industri manufaktur pada tahun 2017 - 2019 mangalami pertumbuhan yang melambat, kecuali industri tekstil, kertas dan barang cetakan yang mengalami kenaikan pertumbuhan yang disebabkan karena adanya Pilpres dan bersifat musiman, sedangkan industri manufaktur yang lain mengalami kontraksi, sehingga porsi industri manufaktur terhadap PDB semakin menurun pada kuartal II tahun 2019 sudah mencapai 19,52\% (Adharsyah, 2019).

Kondisi pertumbuhan yang terus menurun pada sektor manufaktur di Indonesia, mengkhawatirkan dunia industri yang dapat berakibat pada kesulitan keuangan. Kesulitan keuangan berawal dari laba operasi yang negatif, jika hal tersebut berkepanjangan maka akan terjadi default yang akhirnya menyebabkan kebangkrutan, akan tetapi jika perusahaan sudah bisa mendeteksi lebih awal terjadinya kesulitan keuangan dan default, dan pihak manajemen bisa mencari berbagai solusi restrukturisasi sehingga risiko kebangkrutan bisa diminimalkan bahkan dihilangkan. Restrukturisasi merupakan upaya perbaikan kinerja suatu perusahaan dengan menerapkan good corporate governance yaitu tata kelola yang baik yakni adanya transparansi, integritas beretika, responsibilitas, akuntabilitas, independensi dan keadilan, (Djohanputro, 2012). Penerapan good corporate governance memberikan kemungkinan menyelamatkan perusahaan dari kebangkrutan, seperti beberapa perusahaan tersebut di atas yang bisa selamat dari kebangkrutan.

Studi mengenai kesulitan keuangan dan kebangkrutan sampai saat ini masih menarik untuk diteliti, dengan semakin kompleksnya permasalahan yang ada pada saat ini tentunya berbagai masalah yang berkaitan dengan penyebab kebangkrutan masih perlu digali dan penting untuk diprediksi 
agar supaya bisa diantisipasi. Tentunya selain dari sisi internal perusahaan perlu diperhatikan sisi eksternal yang menyangkut kebijakan makro pemerintah, misalnya kebijakan pajak, ketentuan bunga, inflasi, nilai tukar, pengangguran dan pertumbuhan ekonomi yang merupakan bagian dari siklus bisnis yang bisa mempengaruhi kinerja perusahaan khususnya dalam mempertahankan kesulitan keuangan. 


\section{BAB II \\ KINERJA PERUSAHAAN}

\section{A. Kesulitan Keuangan (Financial Distress)}

Kesulitan keuangan merupakan proses yang panjang sebagai suatu siklus dengan tahapan-tahapan yang menggambarkan kondisi keuangan suatu perusahaan menuju pada kebangkrutan. Tahapan tersebut dilalui oleh perusahaan dengan periode tertentu, jika perusahaan bisa menentukan kebijakan dan strategi untuk mempertahankan perusahaan supaya bisa jalan terus, maka kebangkrutan tidak akan terjadi. Kesulitan keuangan pada suatu perusahaan tidak sekaligus diikuti dengan matinya suatu perusahaan, kebangkrutan suatu perusahaan dapat terjadi apabila suatu perusahaan tidak dapat mempertahankan aliran kasnya dalam jangka waktu tertentu (Wruck, 1990). Studi yang pertama dalam prediksi kebangkrutan adalah pada awal abad 20 yaitu pada tahun 1932, ketika Fitzpatrick menggunakan indeks ekonomi untuk menggambarkan kemampuan prediksi default suatu bisnis. Analisis rasio digunakan untuk menilai kinerja kebangkrutan suatu perusahaan dengan menghitung rata-rata dari berbagai rasio seperti arus kas terhadap total hutang, pendapatan bersih terhadap total asset, modal kerja terhadap total asset, pada kurun waktu sepuluh tahun sebelum bangkrut (Li \& Wang, 2018).

Prediksi kebangkrutan merupakan masalah yang menarik untuk diteliti sehingga semakin banyak peneliti setelah Fitzpatrick yang berfokus pada prediksi kebangkrutan diantaranya Winakor dan Smith pada tahun 1935 dan Merwin pada tahun 1942 (Li \& Wang, 2018). Menurut Modigliani dan Miller bahwa hutang akan menghasilkan kebangkrutan, tetapi kebangkrutan saja tidak menurunkan nilai perusahaan. Pada pasar yang sempurna kebangkrutan akan menggeser kepemilikan saham dari pemegang saham kepada pemberi 
hutang tanpa merubah jumlah dari nilai semua investor (Berk, Jonathan; DeMarzo, 2014). Perusahaan yang mempunyai aliran kas tidak stabil, jika terjadi guncangan ekonomi maka akan mudah mengalami kebangkrutan apabila menggunakan terlalu banyak hutang. Ketika perusahaan mengalami masalah pada hutang obligasi maka dapat dikatakan perusahaan tersebut mengalami financial distress (kesulitan keuangan).

Default dapat terjadi ketika investor meminjamkan dana kepada individu atau perusahaan akan tetapi peminjam mengalami kegagalan pada pembayaran bunga dan pokok pinjaman. Pada umumnya peminjam yang mempunyai risiko tinggi terhadap default, mereka harus membayar tingkat bunga yang tinggi, sehingga default dapat diuji dengan mengukur tingkat risiko default terhadap tingkat bunga pinjaman. Kemungkinan kebangkrutan suatu perusahaan adalah pada saat cash flow suatu perusahaan tidak cukup untuk membayar hutang obligasi dalam bentuk bunga dan pokok pinjamannya pada saat jatuh tempo. Kegagalan tersebut tidak secara otomatis mempengaruhi kebangkrutan, tetapi hanya merupakan pemicu dengan semua konsekuensi negatifnya, semakin tinggi volatilitas cashflow maka semakin tinggi pula kemungkinan terjadinya kebangkrutan (Damodaran, 2015).

Pendapat bahwa kegagalan diartikan sebagai ketidakmampuan perusahaan untuk membayar kewajiban keuangannya saat jatuh tempo disampaikan oleh Gerstenberg dalam penelitiannya. Secara operasional, sebuah perusahaan dikatakan telah gagal ketika salah satu dari peristiwa berikut terjadi: kebangkrutan, gagal bayar obligasi, rekening bank yang ditarik berlebihan, atau tidak dibayarkannya dividen saham pilihan. Penelitian yang melakukan pengelompokkan perusahaan gagal dan tidak gagal, serta mengumpulkan data laporan keuangan dan rasionya, menghitung rasio, membandingkan nilai rata-rata, membuat analisa rasio berdasarkan teori dan bukti empiris, membandingkan rata- 
rata ukuran asset, kemudian membandingkan dengan penelitian sebelumnya (Beaver, 1966). Penelitian selanjutnya secara khusus melakukan beberapa perhitungan rasio keuangan dan ekonomi yang akan diselidiki dalam konteks prediksi kebangkrutan dengan metodologi statistik diskriminan ganda yang digunakan (Altman, 1968), yang menghasilkan nilai $\mathrm{Z}$ score, yang akhirnya digunakan oleh banyak peneliti sesudahnya untuk memprediksi kesulitan keuangan, default dan kebangkrutan. Kegagalan perusahaan dalam bisnis merupakan peristiwa yang menghasilkan kerugian besar bagi kreditur dan pemegang saham, sehingga diperlukan prediksi sedini mungkin yang akan mengurangi potensi default (Deakin, 1972). Perubahan suku bunga obligasi sebagai bentuk risiko dihitung sebagai penyebab probabilitas default (Merton, 1974).

Pengembangan model klasifikasi kebangkrutan yang memasukkan input komprehensif pada analisis diskriminan menggunakan sampel dari perusahaan yang bangkrut merupakan eksplorasi dari model yang digunakan pada tahun 1968 dengan lima variabel berdasarkan sampel ZETA, sedangkan model yang baru dikembangkan dengan menggunakan tujuh variabel, dan dengan sampel yang sama hasilnya sedikit lebih akurat. Model Zeta ini bisa memprediksi kebangkrutan perusahaan lima tahun sebelumnya dan sampel dalam model tersebut adalah menggunakan perusahaan di bidang manufaktur dan retail (Altman**, Edward I.; Haldeman, Robert G. ; Narayanan, 1977). Prediksi kebangkrutan dikembangkan dengan waktu yang lebih pendek yaitu dua tahun sebelum terjadinya kebangkrutan, ini merupakan perbaikan dari model sebelumnya (Ohlson, 1980). Metode yang lebih baik dalam memprediksi kebangkrutan diperkenalkan dengan menggunakan neural network, metode ini menjawab kelemahan dari metode yang ada sebelumnya (Wilson, Rick L. ; Sharda, 1994). 
Seperempat sampai sepertiga dari semua perusahaan yang mengalami kesulitan keuangan dalam beberapa tahun telah menyelesaikan restrukturisasi hutang. Salah satu strategi yang memungkinkan pemulihan yang cepat dari perusahaan yang memang layak dan memungkinkan mewujudkan peluang pertumbuhan, maka kreditur bisa menukar hutang perusahaan dengan ekuitas. Kesulitan keuangan menggambarkan sebagai suatu proses yang dinamis yang menjadikan kreditur dapat mempelajari lebih banyak tentang kelangsungan hidup perusahaan yang mengalami kesulitan keuangan, sehingga keputusan likuidasi didasarkan atas informasi yang benar dan mendalam dari efisiensi proses keuangan, struktur modal perusahaan dan kebijakan investasi serta restrukturisasi hutang (Kahl, 2002).

Sampai saat ini definisi kesulitan keuangan masih belum ada kejelasan yang pasti dan baku, sehingga masingmasing mempunyai definisi sendiri. Kondisi kesulitan keuangan terjadi apabila perusahaan mengalami persoalan keuangan yang sudah lama. Persoalan keuangan tersebut dapat terlihat dari berkurangnya pembagian dividen, pabrik yang sudah tidak beroperasi, kerugian yang terus menerus, pemutusan hubungan kerja, CEO mengundurkan diri dan harga saham yang turun drastis. Untuk memudahkan beberapa peneliti menggunakan kebangkrutan sebagai pengukurannya karena kebangkrutan mempunyai definisi lebih jelas dan perusahaan sudah pasti dalam mengalami kebangkrutan (Manurung, 2012).

Proses jangka panjang dalam kesulitan keuangan memiliki dampak pada struktur modal, kebijakan investasi, dan kinerja perusahaan bahkan setelah mereka melakukan restrukturisasi hutang dalam rangka menyelamatkan perusahaan dari kebangkrutan (Kahl, 2002). Sifat jangka panjang dari kesulitan keuangan itu sulit dijelaskan karena merupakan indikator yang tidak sempurna dari kelayakan ekonomi. Jika perusahaan memasuki tahap kesulitan keuangan, masalah yang dihadapi oleh kreditur adalah untuk 
bisa membedakan antara perusahaan ekonomis dan perusahaan yang harus dilikuidasi. Sehingga akan lebih optimal jika kreditur menunda keputusan likuidasi dan menunggu informasi lebih lanjut tentang kelangsungan hidup perusahaan.

Prediksi default dengan menunjukkan bagaimana informasi dari suatu kelompok perusahaan meningkatkan daya prediksi dari model prediksi kebangkrutan yang tradisional, sehingga menghasilkan pandangan tentang pentingnya sumber informasi laporan keuangan konsolidasi termasuk untuk lintas negara. Temuan ini menarik bagi regulator akuntansi, otoritas penegakan hukum, dan auditor, serta lembaga pemberi kredit yang relevan yang melakukan penilaian peringkat kreditnya (Beaver et al, 2019). Tindakan untuk memantau kesehatan keuangan suatu perusahaan yang baru tumbuh saat ini adalah untuk : menentukan keberlanjutan dan pertumbuhan perusahaan di dunia kompetitif, mengidentifikasi tanda-tanda kesulitan keuangan untuk menghindari kebangkrutan, masuknya pemain baru di pasar, pasar keuangan terintegrasi untuk menarik investor dari luar negeri, dan adanya keengganan untuk berinvestasi karena ketidakpastian politik dan politik koalisi (Dhar, Pranam ; Baidya, Bidhan ; Das, Bishnupada ; Bose, 2019).

Penelitian dengan menggunakan data neraca dan informasi tentang kebangkrutan untuk mempelajari hubungan antara investasi, kendala keuangan, dan kebangkrutan di negara pasca-transisi telah dibuktikan dengan ditemukannya bahwa arus kas dan tingkat utang memiliki dampak positif dan signifikan pada tingkat investasi. Masing-masing sub sampel dapat mengungkapkan keberadaan kendala keuangan, diproksikan oleh sensitivitas investasi-arus kas, terbukti terutama pada perusahaan kecil dan menengah. Saat yang sama, tidak ditemukan bukti bahwa perusahaan bangkrut selama periode pengamatan dan menghadapi kendala keuangan yang lebih parah. Perusahaan-perusahaan yang bangkrut secara signifikan memiliki tingkat utang luar negeri dan pinjaman bank yang lebih tinggi (Pospíšil Martin; Schwarz, 2014) . 
Prediksi kegagalan keuangan perusahaan telah memperhitungkan banyak faktor, sebagian besar sesuai dengan rasio keuangan yang berasal dari perhitungan tahunan perusahaan. Krisis saat ini mengakibatkan kenaikan tingkat kepailitan yang tidak masuk akal, hal ini menjelaskan bahwa fenomena kebangkrutan tidak dapat dijelaskan tanpa mengacu pada fenomena kebangkrutan dari variabel ekonomi makro sebagai keseluruhan kondisi ekonomi, dan bukan hanya disebabkan oleh rasio keuangan internal perusahaan (Gonzales, Eduardo Acosta ; Rodriguez, Fernando Fernandez ; Ganga, 2019).

Hubungan antara risiko kebangkrutan dan siklus hidup perusahaan dengan menjalankan Hierarchical Linear Mixed Model (HLM), memberikan hasil empiris bahwa perusahaan selama tahap pengenalan, pertumbuhan dan, penurunan (tahap matang) dari siklus hidup mengalami risiko kebangkrutan yang lebih tinggi atau lebih rendah. Tahap pertumbuhan, risiko kebangkrutan lebih tinggi yang merupakan tahap awal siklus hidup, temuan ini menunjukkan bahwa manajer keuangan harus berhati- hati terhadap lemahnya kondisi keuangan perusahaan pada setiap tahap siklus hidup perusahaan. Studi ini merupakan yang pertama menguji secara empiris hubungan antara tahap siklus hidup perusahaan dan risiko kebangkrutan dan menyatakan bahwa manajer harus memasukkan efek siklus hidup ke dalam perencanaan keuangan dan pengambilan keputusan untuk perusahaan yang berkelanjutan (Akbar, Ahsan; Akbar, Minhas ; Tang, Wenjin ; Qureshi, 2019).

Pengujian dampak pertumbuhan ekonomi, inflasi, suku bunga, nilai tukar, modal, kualitas aset, kualitas manajemen, pendapatan, likuiditas, dan sensitivitas terhadap risiko pasar untuk memprediksi tekanan kepada perbankan dengan menggunakan indeks stabilitas perbankan dan metode analisis logistik ordinal. Hasil menunjukkan bahwa pertumbuhan ekonomi signifikan negatif untuk memprediksi kesulitan perbankan. Faktor-faktor internal seperti modal 
secara positif mempengaruhi tekanan perbankan, sementara kualitas aset, manajemen, dan pendapatan memiliki efek negatif untuk memprediksi tekanan perbankan. Faktor eksternal makro inflasi, tingkat bunga, nilai tukar, likuiditas, dan sensitivitas terhadap risiko pasar tidak secara signifikan mempengaruhi kesulitan keuangan perbankan. Variabel ekonomi makro yang diproksikan dengan pertumbuhan ekonomi berpengaruh signifikan dan negatif terhadap kemungkinan kesulitan perbankan (Wulandari \& Kusairi, 2017).

Penelitian dan pengembangan $(R \mathcal{E} D)$ merupakan salah satu variabel dalam memprediksi kesulitan keuangan dan menganalisis hubungan antara kesulitan keuangan, kinerja, pekerjaan, dan investasi penelitian dan pengembangan (RED) dalam kasus perusahaan multinasional (MNCs). Model logit bersyarat dan hazard digunakan untuk memprediksi kesulitan keuangan, sementara model proses campuran bersyarat digunakan untuk mendapatkan perkiraan yang konsisten dan efisien. Kesulitan keuangan menimbulkan keterbatasan dalam kinerja, pekerjaan, dan investasi penelitian dan pengembangan. Lindung nilai terhadap risiko mengurangi dampak kesulitan keuangan pada $R \mathcal{E} D$ dan pada setiap negara berbeda-beda, sehingga temuan ini menunjukkan bahwa perusahaan multinasional memainkan peran yang berbeda di berbagai negara dalam memberikan kontribusi terhadap investasi penelitian dan pengembangan selama periode kesulitan keuangan (Apergis, Nicholas ; Bhattacharya, Mita ; Inekwe, 2019).

Kinerja prediksi non-akuntansi, informasi pasar dan tata kelola bervariasi pada dua pasar yang berbeda, informasi akuntansi memberikan akurasi prediksi yang lebih tinggi untuk pasar yang matang, diikuti oleh informasi pasar dan tata kelola. Informasi non-keuangan pada variabel tata kelola memiliki kemampuan prediksi yang lebih tinggi daripada informasi keuangan di pasar negara berkembang, sehingga baik pasar yang sedang berkembang maupun yang sudah 